\title{
Money for Nothing and Your Chips for Free? The Anatomy of the PC Wage Differential
}

\author{
John P. Haisken-DeNew \\ The German Institute for Economic Research, Berlin and IZA, Bonn \\ Christoph M. Schmidt \\ University of Heidelberg, CEPR London and IZA, Bonn
}

\author{
Discussion Paper No. 86 \\ December 1999
}

\author{
IZA \\ P.O. Box 7240 \\ D-53072 Bonn \\ Germany \\ Tel.: +49-228-3894-0 \\ Fax: +49-228-3894-210 \\ Email: iza@iza.org
}

This Discussion Paper is issued within the framework of IZA's research areas The Future of Work and General Labor Economics. Any opinions expressed here are those of the author(s) and not those of the institute. Research disseminated by IZA may include views on policy, but the institute itself takes no institutional policy positions.

The Institute for the Study of Labor (IZA) in Bonn is a local and virtual international research center and a place of communication between science, politics and business. IZA is an independent, nonprofit limited liability company (Gesellschaft mit beschränkter Haftung) supported by the Deutsche Post AG. The center is associated with the University of Bonn and offers a stimulating research environment through its research networks, research support, and visitors and doctoral programs. IZA engages in (i) original and internationally competitive research in all fields of labor economics, (ii) development of policy concepts, and (iii) dissemination of research results and concepts to the interested public. The current research program deals with (1) mobility and flexibility of labor markets, (2) internationalization of labor markets and European integration, (3) the welfare state and labor markets, (4) labor markets in transition, (5) the future of work, (6) project evaluation and (7) general labor economics.

IZA Discussion Papers often represent preliminary work and are circulated to encourage discussion. Citation of such a paper should account for its provisional character. 
IZA Discussion Paper No. 86

December 1999

\section{ABSTRACT \\ Money for Nothing and Your Chips for Free? The Anatomy of the PC Wage Differential ${ }^{*}$}

In this paper, the role of the computer at the workplace will be examined in determining the wage structure in Germany. Following Krueger (1993) and using the German SocioEconomic Panel (GSOEP), cross-sectional wage regression results from 1997 and panel results from 1984-1997 are presented. It is shown that the wage premium attributed to using a computer at work using cross-sectional results for 1997 is around $7 \%$. Further it is shown that computer usage is very heterogeneous depending on which industry one works in. In cross-section, hypothesis tests show that several industries and almost all firm size categories exhibit very different wage differentials depending on computer usage at the workplace. As DiNardo and Pischke (1997) stress the need for panel data to control for unmeasured individual effects, we use GSOEP 1984-1997 panel data, where a random effects and fixed effects estimator were run in the wage estimation. We confirm the results that Entorf and Kramarz (1997) had for France, that in Germany the coefficient for computer usage at the workplace did not remain stable and although just barely significant, was reduced to mere $1 \%$ with individual fixed effects. We conclude that there are no computer usage wage differentials worth speaking of, once one controls adequately for unobserved individual heterogeneity.

JEL Classification: J31, O33, C20

Keywords: Computer wage premium, skill-biased technological change, inter-industry wage differentials, Germany

John P. Haisken-DeNew

The German Institute for

Economic Research (DIW-Berlin)

Königin-Luise-Str. 5

D-14195 Berlin

Germany

Tel.: +49-30-89789-461

FAX: +49-30-89789-200

Email: jhaiskendenew@diw.de

\footnotetext{
"This paper celebrates Kolya Eike Haisken-DeNew, born August 17, 1998 in Berlin, Germany. The authors would like to thank Markus Pannenberg, Joachim Frick and Gert Wagner (DIW-Berlin) for their extremely helpful comments and suggestions.
} 


\section{Introduction}

In the United States, the 1980s witnessed a widening inequality both across skill groups and within narrowly defined groups of workers. The interpretation of these changes dominating the labor literature is an explanation in terms of skill-biased technological change within industries. Krueger (1993) examined the role of the computer as a determinant of wages and whether this computer premium can account for changes in the wage structure in the 1980s. He found significant work-related computer usage premia using CPS data for 1984 and 1989. In this new and very exciting strand of literature, DiNardo and Pischke (1997), and Entorf and Kramarz (1997) have shown that for Germany and France respectively, cross-sectional results do indeed demonstrate work-related computer usage to generate wage premia. Entorf and Kramarz (1997) however when using a panel and controlling for unobserved individual heterogeneity, find that these computer premia for France are rendered insignificant. DiNardo and Pischke (1997) stress the need for panel data to control for unmeasured individual effects. They find wage effects for using, among other things, a pencil and hand calculator. In contrast, Bell (1996) using British longitudinal data with additional skills and aptitude test information confirms the findings of Krueger (1993) and finds that up to one half of the increase in the return to education can be attributed to various measures of technical skill (computer usage being one of them).

The intent of this paper is to closely examine the role of computer usage at work and its effect on the wage structure in Germany. Using cross-section data from the German Socio-Economic Panel for 1997, it is concluded that there indeed is a computer wage premium of around $7 \%$, however, after controlling adequately for unobserved individual heterogeneity using panel estimators for 1984-1997, the wage premium at $1 \%$ is barely significant and hardly worth speaking of.

\section{Background}

Krueger (1993) attempted to link the observed change in the return to education in the United States in the 1980s to increasing popularity of the computer at the workplace. He found that wage differentials gained by those high skilled workers using a computer at work could account for $42 \%$ of the increase of the return to education in the private sector in this time period. In the analysis, Krueger used two waves of the October CPS from 1984 and 1989 and found that women were more likely to be using a computer at work, and that in some particular industries more than others, such as the Banking sector, computers were prevalent. He found that males and females aged 29 to 39 and the highest educated tended to use computers the most. Krueger (1993) found raw wage differentials (without any controls) for PC work use in 1984 to be $28 \%$, rising in 1989 to $33 \%$.

Workers with unobserved skills could be thought to enjoy wage differentials seemingly due to computer usage at work, whereas the real effect came from their ability. By including computer usage at home and its interaction with computer usage at work, any bias in the PC usage effect at work due to omitted factors that are associated with computer use in general, were thought to be eliminated. 
Indeed Krueger found little change. The wage differential in general for using a computer at the workplace, depending on the specification of the estimation, was found to be between 10 and $15 \%$.

Entorf and Kramarz (1994) and Entorf and Kramarz (1997) examine the role of unmeasured ability in the estimations of the computer usage wage premium. They use French Labor Force Survey panel data from 1985-1987 with additional merged firm-level information. For more than 15,000 persons, they have information concerning technology usage at the workplace such that the individuals can be identified over time for a maximum of 3 years in a rotating panel, making up a total of more than 35,000 person-year observations in the panel. In cross-sections, firm effects do not alter the computer usage wage premia. However, they further conclude that indeed, using fixed-effects panel estimation, all computer usage wage premia except for computer experience effects disappear. They state, "In particular, to check the effect of NT [New Technologies] on wages, panel data on individuals is necessary, since, as we saw, cross-section data matching workers and firms do not capture the individual ability component of the wage." 1

DiNardo and Pischke (1997) refute the ability to measure true computer effects on wages. Using cross-sectional data for Germany from the German Qualification and Career Survey 1979, 1985-86, 1991-92 they compare German results to the American CPS, replicating Krueger (1993). They include a list of other "office tools" such as pencils, telephones, hand calculator, sitting while working, where one might not expect any particular wage premium to arise. However, they find significant differentials in Germany. The criticism is then, what is actually being measured by a computer usage indicator in a wage regression? They are skeptical of any causal relationship between computer usage and wage premia, "these findings cast some doubt on the literal interpretation of the computer use wage differential as reflecting true returns to computer use or skill." Further, they stress the need for panel data to control for unobserved individual heterogeneity, "Since Krueger relies on cross-section data, he cannot and does not control for individual fixed effects." ${ }^{2}$

Bell (1996) uses the unique British National Child Development Study from 1981 and 1991 to examine the role of ability and individual heterogeneity in looking at the computer wage premium issue. Here additional test scores are available for reading comprehension and mathematical aptitude. In cross-section, he finds a large significant computer wage premium of $11 \%$, even after controlling for additional skills such as math, planning ability, organizational capabilities. ${ }^{3}$ Using his 1991-1981 difference model, he finds a significant computer wage premium of $13 \%$. He finds, "we show that wages are positively related to these [technical] skills and that there is little evidence that unobserved characteristics of either the individual or the firm are driving the correlation. Furthermore it is the use of these skills in the workplace that is important for wages not simply ability. This suggests that a productivity enhancing interpretation is most appropriate." 4

\footnotetext{
${ }^{1}$ See Entorf and Kramarz (1997), p. 1504.

${ }^{2}$ See DiNardo and Pischke (1997), p. 291.

${ }^{3}$ See Bell (1996) Table 5, column (4), p. 28.

${ }^{4}$ See Bell (1996), p. 22.
} 


\section{The Data}

To attempt to control for individual unobserved heterogeneity ${ }^{5}$, panel data will be used for Germany. The German Socio-Economic Panel (GSOEP) is panel dataset from 1984 to the present consisting of some 13,500 individuals and roughly 7,000 households living in West Germany (the "old" states) and East Germany (the "new states"). Foreigners and recent migrants are also included in the sample. Individuals from 1984 to 1997 have been closely followed. The German version of the GSOEP data is used here, although the same analysis can be made with the international "scientific use" version, albeit with approximately $5 \%$ fewer observations. ${ }^{6}$

The sample used from the GSOEP data was all males and females full-time employed (up to 80 hours/week) living in west Germany, aged 25-60 in all time periods. ${ }^{7}$ The GSOEP asks very detailed income information of all adult respondents directly, including gross and net monthly income (uncensored), and various other components. The GSOEP differentiates also between actual and contractual hours worked per week. In this analysis, the maximum of the two is used. This avoids undercounting the nominal 40-hour manager/salaried jobs on the top end, and on the bottom end, where a full time employed person actually only worked say 10 hours that interview week due to sickness, but would normally work 40 .

The GSOEP uses a quasi 2-digit industry classification scheme modeled after the macro-level official statistics from the German Statistical Office. Due to cell-size considerations and keeping in mind the wage-bargaining mechanisms in Germany, those industries that "collectively bargain together" are more or less also grouped together in the analysis. For more discussion on inter-industry wage differentials see Haisken-DeNew and Schmidt (1998).

In three waves of the GSOEP the question was asked whether one had a PC in the household (among other household items). Since 1993 the percentage of households having a PC has climbed steadily from $14.4 \%$ to $21.2 \%$ in 1995 and $24.5 \%$ in 1996 . In 1997 for the first time, the following question was asked of all adult respondents in the household: Do you use a computer at home and/or at work, and if so, since what year at home, and since what year at work? ${ }^{8}$ The share of persons using a PC at home was $37 \%$ and at work 51\%. If one examines the upward trend of those having

\footnotetext{
${ }^{5}$ Unfortunately there is no information of any kind in the GSOEP concerning school grades or achievement scores as possible controls for "ability".

${ }^{6}$ See Haisken-DeNew and Frick (1998) for extensive documentation on the GSOEP and Wagner, Burkhauser, and Behringer (1993) for more details on the "scientific use" version.

${ }^{7}$ The data were processed using the TDA distribution of the GSOEP. The data are available in ready-made Windows binary datafiles in Stata, SAS, SPSS and TDA format as well as in ASCII format. Retrieval/match files can be automatically generated using the bilingual (German/English) SOEPINFO-WWW on the SOEP Homepage http://www.diw-berlin.de/soep. This feature is available for all supported statistical packages.

${ }^{8}$ The original German text from the 1997 personal questionnaire is: "Q4. Benutzen Sie privat oder beruflich (bzw. in Ihrer Ausbildung) einen Computer? Gemeint sind hier Personal-Computer (PC) aber auch Grossrechneranlagen, jedoch nicht reine Spielcomputer! [Ja/Nein], ich benutze [einen/keinen] Computer [privat/beruflich] und zwar seit ...". For previous years, the PC usage indicator is simply set to 1 for that year that the person started using a computer and remains 1 for all following years.
} 
a computer at home, then it makes sense to expect this upward trend over time would hold for the share of those using a computer at work. Using a computer at home is highly correlated with using a computer in the workplace. Of those who use a computer at home, $86 \%$ also use a computer at work, and this share is even higher for females (94\%)! Or put the other way around, $60 \%$ of those who use a computer at work, also do at home. The share of women using a computer in 1997 at work is $57 \%$ whereas with men it is only $49 \% .^{9}$

Table 1: Computer Usage Rates at Work and Home

\begin{tabular}{rrr}
\hline Year & $\begin{array}{r}\text { Work } \\
\text { (\% share) }\end{array}$ & $\begin{array}{r}\text { Home } \\
\text { (\% share) }\end{array}$ \\
\hline 1984 & 9.23 & 3.68 \\
1985 & 17.33 & 5.52 \\
1986 & 19.39 & 5.47 \\
1987 & 21.59 & 6.98 \\
1988 & 24.36 & 8.00 \\
1989 & 25.39 & 9.71 \\
1990 & 32.10 & 12.88 \\
1991 & 35.49 & 14.81 \\
1992 & 39.28 & 18.64 \\
1993 & 39.41 & 18.84 \\
1994 & 43.54 & 21.86 \\
1995 & 48.68 & 37.56 \\
1996 & 54.02 & 34.69 \\
1997 & 52.11 & \\
\hline & & \\
\hline
\end{tabular}

Smaller firms of under 20 employees in size have computer usage rates of up to $37 \%$, whereas firms of size 20-1999 have 53\% and very large firms of more than 2000 have a computer usage rate of $70 \%$. As for the industrial structure, those working in the Banking sector have the highest usage rate of $93 \%$ whereas lowest usage is found in the Plastics industry at 13\%. Intuitively, the occupational structure is very similar: the highest levels for managers and office workers at around 87\%-93\% and the lowest for production/manufacturing workers at $20 \%$. The most active age-group using PCs at the workplace is $30-34$ at $58 \%$, although the broader age category 30-49 is very similar at approximately $55 \%$.

\section{Empirical Applications}

For the first part of the analysis, the 1997 cross-section will be examined. Hourly wage regressions are run controlling for PC work and home use and their interaction. The second part of the analysis will examine the interaction of computer usage at work and other indicators such as firm size and industry. Finally, in the third part of the analysis, in order to look closer at the effects of unobserved individual heterogeneity, the entire panel will be used.

For the unbalanced panel analysis we use only those individuals who were full-time employed in 1997 and had complete valid information for at least one other year previously, amounting to more

\footnotetext{
${ }^{9}$ All descriptive statistics are appropriately weighted.
} 
than 12,000 person-year observations or approximately 1,600 individuals. All wage information has been deflated by the official OECD MEI consumer price index (base year 1990), relevant in the panel or pooled analysis.

Control variables include: year dummies for the longitudinal models, 3 geographical, 3 age, marital status, 5 firm size, 5 occupation (close to 1-Digit ISCO), and job status dummies, with (years of) education entering as a "continuous" variable. Gender and nationality were not included in the panel analysis for direct comparability between the models: simple pooled, random effects panel and fixed effects panel.

\section{A. Cross-Section Wage Differentials in 1997}

For simplicity we will call the PC usage at the workplace "PC-Work", PC usage at home "PCHome" and the interaction between the two, "PC-Both". Here we will examine several variations of the standard model: (a) "raw differentials" regression with PC-Work (b) "raw differentials" regression with PC-Home (c) standard regression, (d) standard regression with PC-Work, (e) standard regression with $\mathrm{PC}-\mathrm{Home}$, (f) standard regression with $\mathrm{PC}-$ Work and $\mathrm{PC}-\mathrm{Home}$, (g) standard regression with PC-Work, PC-Home, PC-Both.

Table 2 summarizes the 1997 cross-sectional results. ${ }^{10}$ By regressing hourly wages on a constant and the PC-Work in column (a), we find the raw differential for PC-Work to be $22 \%(\mathrm{t}=15.3)$ and similarly in column (b) for PC-Home $24 \%(\mathrm{t}=15.5)$. The PC usage indicators are added to standard wage regression specifications with the usual controls for such things as human capital etc, the PCWork premium drops in column $(\mathrm{d})$ to $7 \%(\mathrm{t}=4.9)$ and for PC-Home in column (e) $6 \%(\mathrm{t}=4.4)$. Including both PC usage indicators drop the premia further in column $(\mathrm{f}): 5.7 \%(\mathrm{t}=3.7)$ for PC-Work and $4.5 \%(\mathrm{t}=3.0)$ for PC-Home. Including the PC indicators and their interaction PC-Both as seen in column $(\mathrm{g})$, does not change the situation much.

Interacting PC usage at work with the industry indicators show significantly higher differentials in the Chemicals (11\%), Metal (10\%), Wholesale/Retail (4\%), Transport (10\%) and Other Services (5\%) industries, using pair-wise hypothesis tests (i.e. is the industry differential for industry $\mathrm{X}$ significantly larger when using a PC or not). Table 3 reports these results, and those industries' differentials marked with an "a" are shown to be significantly higher when using a PC. Industry differentials in Table 3 are reported as deviations from a weighted average as in Haisken-DeNew and Schmidt (1997). Interacting PC usage at work with firm size show that at almost all firm sizes, those who use a PC experience wage differentials in the order of $5-10 \%$. For those working in the largest firms (2000 employees or more), there is no discernible difference for using a PC as the overwhelming majority (70\%) of employees of such firms use computers anyway. Table 4 reports these results for firm size and significantly higher firm size differentials with PC usage are similarly marked with an "a". Firm size differentials in Table 4 are also reported as deviations.

\footnotetext{
${ }^{10}$ Appendix Table 7 gives the complete table.
} 
Table 2: OLS Wage Regression 1997 Cross-Section: PC-Work, PC-Home \& PC-Both

\begin{tabular}{|c|c|c|c|c|c|c|}
\hline \multirow[b]{2}{*}{ Model } & \multicolumn{2}{|c|}{ Raw Differential } & \multicolumn{4}{|c|}{ Complete Model with Standard Controls } \\
\hline & (a) & (b) & (d) & (e) & (f) & (g) \\
\hline $\begin{array}{l}\text { Observations } \\
\mathrm{R}^{2}\end{array}$ & $\begin{array}{l}1855 \\
0.112\end{array}$ & $\begin{array}{l}1855 \\
0.114\end{array}$ & $\begin{array}{l}1855 \\
0.511\end{array}$ & $\begin{array}{l}1855 \\
0.510\end{array}$ & $\begin{array}{l}1855 \\
0.513\end{array}$ & $\begin{array}{l}1855 \\
0.513\end{array}$ \\
\hline PC-Work & $\begin{array}{c}0.218 \\
(15.268)^{*}\end{array}$ & - & $\begin{array}{c}0.072 \\
(4.889)^{*}\end{array}$ & - & $\begin{array}{c}0.057 \\
(3.663)^{*}\end{array}$ & $\begin{array}{c}0.058 \\
(3.430)^{*}\end{array}$ \\
\hline PC-Home & - & $\begin{array}{c}0.243 \\
(15.447)^{*}\end{array}$ & - & $\begin{array}{c}0.062 \\
(4.440)^{*}\end{array}$ & $\begin{array}{c}0.045 \\
(3.044)^{*}\end{array}$ & $\begin{array}{c}0.050 \\
(1.773)^{*}\end{array}$ \\
\hline PC-Both & - & - & - & - & - & $\begin{array}{l}-0.007 \\
-0.207)\end{array}$ \\
\hline
\end{tabular}

${ }^{*}$ coefficient significant at 5\%-level, one-tailed test, t-values in parentheses

\section{B. Spurious Differentials and Unobserved Heterogeneity}

To get at the issues of spurious effects and unobserved individual heterogeneity, two strategies will be followed. As Krueger (1993) suggested, using a computer at home might control for some unobserved individual characteristics omitted from the previous estimations, and thus should reduce some bias in the estimation. Here the cross-sectional results are run again, including PC usage at home and its interaction with PC usage at work.

To further control for unobserved individual heterogeneity, we compare three estimators with the panel information: simple pooled OLS, a random effects panel analysis, and a fixed effects panel analysis. In the GSOEP, there are no further detailed questions about the tools used at the workplace, such as calculators, pencils and so on. So, a direct comparison cannot be made with DiNardo and Pischke (1997) with respect to these tools. Further, there are no "aptitude test scores" in the GSOEP, as used by Krueger (1993) in his "High School and Beyond" evidence.

For the panel analysis, all those working full-time in 1997 and having worked at least one year previously (with complete valid information) were included in the sample. Obviously this does have some implications for the sample. Due to usual attrition effects in a panel that has been going of for 14 years, $61 \%$ of all individuals who started in 1984 are no longer in the sample by 1997. Of course on the other hand, households have also gotten larger when sample members marry or move in together with people outside the original sample. Also when youths reach legal age, they also receive a questionnaire directly. Further, one must satisfy the age condition (25-60) in all years, leading to a "younger sample" in the earlier years, i.e. to be 25-60 in 1997, one must have been 25-47 in 1984. Clearly the retrospective information is not as good as if the computer usage question had been asked in each and every year, nonetheless it does offer some insights into the development of computer usage in Germany. 
Table 3: PC Usage at Work Interacted with Industry

\begin{tabular}{|c|c|c|}
\hline Industry & PC Not Used & PC Used \\
\hline 2. Energy & $\begin{array}{l}0.002 \\
(0.034)\end{array}$ & $\begin{array}{l}0.034 \\
(0.710)\end{array}$ \\
\hline 3.1 Chemicals ${ }^{a}$ & $\begin{array}{l}0.002 \\
(0.080)\end{array}$ & $\begin{array}{c}0.115 \\
(3.755)^{*}\end{array}$ \\
\hline 3.2 Plastics & $\begin{array}{l}0.036 \\
(0.806)\end{array}$ & $\left(\begin{array}{l}-0.122 \\
-1.400)\end{array}\right.$ \\
\hline 3.3 Stone & $\begin{array}{c}-0.029 \\
(-0.429)\end{array}$ & $\begin{array}{l}0.023 \\
(0.285)\end{array}$ \\
\hline $3.4 \mathrm{Metal}^{a}$ & $\begin{array}{l}0.017 \\
(1.160)\end{array}$ & $\begin{array}{c}0.118 \\
(8.082)^{*}\end{array}$ \\
\hline 3.5 Wood & $\left.\begin{array}{l}0.007 \\
0.196\end{array}\right)$ & $\begin{array}{c}0.056 \\
(1.174)\end{array}$ \\
\hline 3.6 Textiles & $\begin{array}{c}-0.210 \\
(-4.829)^{*}\end{array}$ & $\begin{array}{l}-0.066 \\
(-0.759)\end{array}$ \\
\hline 3.7 Food & $\begin{array}{c}-0.087 \\
(-2.324)^{*}\end{array}$ & $\begin{array}{l}-0.001 \\
(-0.021)\end{array}$ \\
\hline 4. Construction & $\begin{array}{l}0.024 \\
(1.155)\end{array}$ & $\begin{array}{c}0.083 \\
(1.834)^{*}\end{array}$ \\
\hline 5. Wholesale/Retail ${ }^{a}$ & $\begin{array}{c}-0.130 \\
(-4.871)^{*}\end{array}$ & $\begin{array}{c}-0.065 \\
(-2.666)^{*}\end{array}$ \\
\hline 6. Transport ${ }^{a}$ & $\begin{array}{c}-0.114 \\
(-3.537)^{*}\end{array}$ & $\begin{array}{l}-0.004 \\
(-0.104)\end{array}$ \\
\hline 7. Banking & $\begin{array}{l}0.055 \\
(0.670)\end{array}$ & $\begin{array}{c}0.084 \\
(3.090)^{*}\end{array}$ \\
\hline 8. Other Services ${ }^{a}$ & $\begin{array}{c}-0.103 \\
(-4.529)^{*}\end{array}$ & $\begin{array}{c}-0.053 \\
(-2.582)^{*}\end{array}$ \\
\hline 9. Non-Profit & $\begin{array}{l}-0.034 \\
(-0.755)\end{array}$ & $\begin{array}{l}-0.019 \\
(-0.396)\end{array}$ \\
\hline
\end{tabular}

The panel model specifications include: (a) the standard variables and PC-Work, (b) the previous model plus PC-Home and (c) the previous model and the interaction PC-Both. Table 5 summarizes the computer usage coefficients from the panel analysis. ${ }^{11}$

In Table 5, the results from 9 different regressions are presented: (a) 3 estimators: pooled OLS, random effects and fixed effects, and (b) 3 model specifications: sequentially adding PC-Home and PC-Both to a model with PC-Work. To illustrate how seriously one might be mislead if one fails to include controls for individual heterogeneity, we see that the pooled OLS coefficient on PC-Work is large at $9 \%$ (first column, first row) and highly significant $(\mathrm{t}=15)$. Using (individual) random effects panel drops the PC-Work effect down to less than half at $4 \%(\mathrm{t}=7.0)$. Using the (individual) fixed effects panel estimator drops this even further to less than a quarter of the OLS pooled coefficient

\footnotetext{
${ }^{11}$ See Appendix Table 8 through Table 10 for the full-length panel results (time dummy coefficients $85-97$ have been left out of the tables for brevity).
} 
Table 4: PC Usage at Work Interacted with Firm Size

\begin{tabular}{|l|cc|}
\hline Firm Size (Number Employees) & PC Not Used & PC Used \\
\hline Under $20^{a}$ & -0.143 & -0.047 \\
$20-199^{a}$ & $(-8.974)^{*}$ & $(-2.244)^{*}$ \\
& -0.074 & 0.033 \\
$200-1999^{a}$ & $(-5.569)^{*}$ & $(1.951)^{*}$ \\
& -0.017 & 0.044 \\
$2000+$ & $(-1.292)$ & $(2.834)^{*}$ \\
& 0.078 & 0.112 \\
& $(4.760)^{*}$ & $(7.866)^{*}$ \\
\hline
\end{tabular}

size at $2 \%(\mathrm{t}=3.5)$ ! When one controls for PC-Home, with PC-Both, the PC-Work coefficient from the pooled OLS estimator is still very strong $6 \%$ and significant $(\mathrm{t}=10)$. We see here that merely by including PC-Home and PC-Both additionally in the specification, as Krueger (1993) suggests, does not prove to be very effective in controlling for ability effects. However, when combining (individual) fixed effects and these additional PC usage indicators, one sees that PC-Work, although still barely significant, has been reduced to a mere $1 \%$ for Germany. Further the coefficients in the same model for PC-Home and PC-Both are both small and very insignificant. These results corroborate largely what Entorf and Kramarz (1997) have found for France.

\section{Conclusions}

In this paper, the German Socio-Economic Panel dataset from 1984 to 1997 was used and indeed cross-sectional results from 1997 indicate a highly significant wage premium of $7 \%$ for computer usage at work in Germany. We conclude that although cross-sectional evidence may deliver appealing initial results when analyzing the wage differential of computer usage, for instance as in Krueger (1993) for the United States, one must include adequate controls for unobserved individual heterogeneity to avoid over-interpreting the results. Simply adding indicators for PC usage at home and interactions between home and work usage are alone insufficient to account for possible "ability" effects. Using all waves and the pooled OLS estimator, the wage premium of using a PC at work is almost $9 \%$ and is highly significant, however when using a panel estimator with individual fixed-effects and controlling for computer related skills, this premium all but disappears to $1 \%$ and is barely significant, confirming the results of Entorf and Kramarz (1997) for France. In Germany, we find no PC usage wage premium to speak of. This paper extends the results from DiNardo and Pischke (1997) with respect to the data, as one can directly control for unobserved individual heterogeneity using panel data. The GSOEP offers a unique opportunity to examine this question as it provides 14 years of panel information. We 
Table 5: GSOEP Panel Results (1984-1997)

\begin{tabular}{|c|c|c|c|c|}
\hline & Model & POOLED OLS & RE-PANEL & FE-PANEL \\
\hline 1 & PC-Work & $\begin{array}{c}0.0856 \\
(14.859)^{*}\end{array}$ & $\begin{array}{c}0.0419 \\
(7.018)^{*}\end{array}$ & $\begin{array}{c}0.0205 \\
(3.542)^{*}\end{array}$ \\
\hline \multirow[t]{2}{*}{2} & PC-Work & $\begin{array}{c}0.0595 \\
(9.857)^{*}\end{array}$ & $\begin{array}{c}0.0330 \\
(5.362)^{*}\end{array}$ & $\begin{array}{c}0.0169 \\
(2.575)^{*}\end{array}$ \\
\hline & PC-Home & $\begin{array}{c}0.0897 \\
(13.383)^{*}\end{array}$ & $\begin{array}{c}0.0341 \\
(5.090)^{*}\end{array}$ & $\begin{array}{c}0.0145 \\
(2.062)^{*}\end{array}$ \\
\hline \multirow[t]{3}{*}{3} & PC-Work & $\begin{array}{c}0.0626 \\
(9.714)^{*}\end{array}$ & $\begin{array}{c}0.0312 \\
(4.727)^{*}\end{array}$ & $\begin{array}{c}0.0144 \\
(2.056)^{*}\end{array}$ \\
\hline & PC-Home & $\begin{array}{c}0.1046 \\
(8.150)^{*}\end{array}$ & $\begin{array}{c}0.0267 \\
(2.311)^{*}\end{array}$ & $\begin{array}{l}0.0052 \\
(0.436)\end{array}$ \\
\hline & PC-Both & $\begin{array}{c}-0.0202 \\
(1.365)\end{array}$ & $\begin{array}{l}0.0100 \\
(0.779)\end{array}$ & $\begin{array}{l}0.0128 \\
(0.977)\end{array}$ \\
\hline
\end{tabular}

Note: $1984-1997, \mathrm{~N}=12482$, People=1625

*coefficient significant at $5 \%$-level one-tailed test, $t$-values in parentheses

suspect that part of the inability of Bell (1996) to find strong "ability" effects is due to the fact that only two waves were available with a relatively small sample size. In stark contrast, we find that in this analysis for Germany, unobserved individual heterogeneity or ability plays the key role in effectively explaining away the apparent wage premium for using a computer at work. 


\section{References}

BeLl, B. D. (1996): "Skill-Biased Technical Change and Wages: Evidence for a Longitudinal Data Set," University of Oxford.

Dinardo, J. E., And J.-S. Pischke (1997): "The Returns to Computer Use Revisited: Have Pencils Changed the Wage Structure Too?," Quarterly Journal of Economics, 1, 291-303.

Entorf, H., And F. Kramarz (1994): "The Impact of New Technologies on Wages: Lessons from Matching Panels on Employees and their Firms," Discussion Paper 9407, CREST-INSEE-Paris.

— (1997): "Does Unmeasured Ability Explain the Higher Wages of New Technology Workers?," European Economic Review, 41, 1489-1509.

Haisken-Denew, J. P., and J. R. Frick (1998): Desktop Companion to the German Socio-Economic Panel Study (GSOEP). German Institute for Economic Research, Berlin.

Haisken-DeNew, J. P., And C. M. Schmidt (1997): "Inter-Industry and Inter-Region Differentials: Mechanics and Interpretation," The Review of Economics and Statistics, 79(3), $516-521$.

(1998): "Industry Wage Differentials Revisited: A Longitudinal Comparison of Germany and USA (1984-1996)," Discussion Paper 2?, Institute for the Study of Labor (IZA-Bonn).

Krueger, A. B. (1993): "How Computers have Changed the Wage Structure: Evidence from Microdata, 1984-1989," Quarterly Journal of Economics, 1, 33-60.

Wagner, G. G., R. V. Burkhauser, and F. Behringer (1993): "The English Language Public Use File of the German Socio-Economic Panel Study," The Journal of Human Resources, 28(2), $429-433$. 
Table 6: Major Hardware and Software Events in PC History

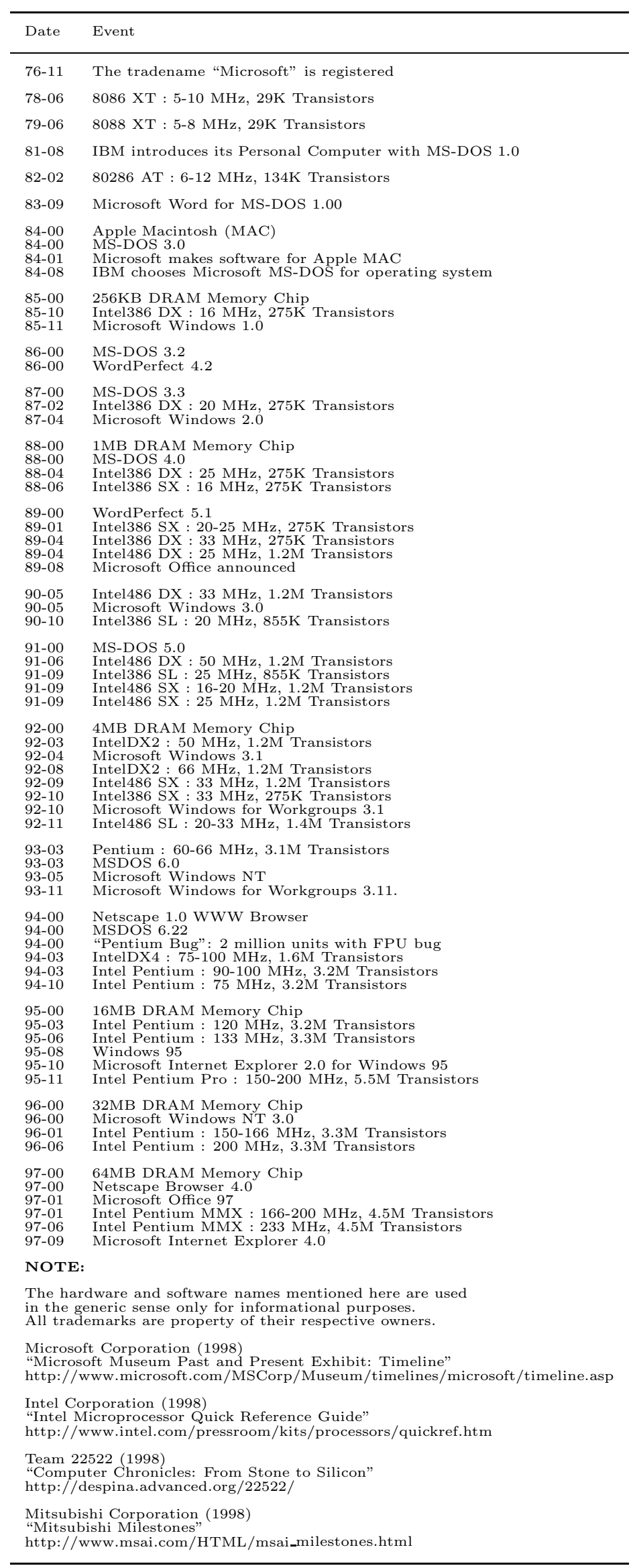


A Appendix: Tables NOT intended for publication! 
Table 7: OLS Wage Regression 1997 Cross-Section: PC-Work, PC-Home \& PC-Both

\begin{tabular}{|c|c|c|c|c|c|c|c|}
\hline Model & (a) & (b) & (c) & (d) & (e) & (f) & (g) \\
\hline $\begin{array}{l}\text { Observations } \\
\mathrm{R}^{2} \\
\text { F-Test } \\
\text { Prob }\end{array}$ & $\begin{array}{c}1855 \\
0.112 \\
233.100 \\
0.000\end{array}$ & $\begin{array}{c}1855 \\
0.114 \\
238.590 \\
0.000\end{array}$ & $\begin{array}{c}1855 \\
0.504 \\
57.940 \\
0.000\end{array}$ & $\begin{array}{c}1855 \\
0.511 \\
57.620 \\
0.000\end{array}$ & $\begin{array}{c}1855 \\
0.510 \\
57.360 \\
0.000\end{array}$ & $\begin{array}{c}1855 \\
0.513 \\
56.450 \\
0.000\end{array}$ & $\begin{array}{c}1855 \\
0.513 \\
54.810 \\
0.000\end{array}$ \\
\hline PC-Work & $\begin{array}{c}0.218 \\
(15.268)^{*}\end{array}$ & - & - & $\begin{array}{c}0.072 \\
(4.889)^{*}\end{array}$ & - & $\begin{array}{c}0.057 \\
(3.663)^{*}\end{array}$ & $\begin{array}{c}0.058 \\
(3.430)^{*}\end{array}$ \\
\hline PC-Home & - & $\begin{array}{c}0.243 \\
(15.447)^{*}\end{array}$ & - & - & $\begin{array}{c}0.062 \\
(4.440)^{*}\end{array}$ & $\begin{array}{c}0.045 \\
(3.044)^{*}\end{array}$ & $\begin{array}{c}0.050 \\
(1.773)^{*}\end{array}$ \\
\hline PC-Both & - & - & - & - & - & - & $\begin{array}{l}-0.007 \\
(-0.207)\end{array}$ \\
\hline Constant & $\begin{array}{c}4.357 \\
(454.390)^{*}\end{array}$ & $\begin{array}{c}4.386 \\
(521.114)^{*}\end{array}$ & $\begin{array}{c}4.047 \\
(75.050)^{*}\end{array}$ & $\begin{array}{c}4.056 \\
(75.645)^{*}\end{array}$ & $\begin{array}{c}4.052 \\
(75.511)^{*}\end{array}$ & $\begin{array}{c}4.058 \\
(75.844)^{*}\end{array}$ & $\begin{array}{c}4.056 \\
(75.471)^{*}\end{array}$ \\
\hline Age: $25-34$ & - & - & $\begin{array}{c}0.086 \\
(6.133)^{*}\end{array}$ & $\begin{array}{c}0.088 \\
(6.290)^{*}\end{array}$ & $\begin{array}{c}0.088 \\
(6.250)^{*}\end{array}$ & $\begin{array}{c}0.089 \\
(6.341)^{*}\end{array}$ & $\begin{array}{c}0.089 \\
(6.343)^{*}\end{array}$ \\
\hline Age: $35-44$ & - & - & $\begin{array}{c}0.137 \\
(9.130)\end{array}$ & $\begin{array}{c}0.138 \\
(9.251)^{*}\end{array}$ & $\begin{array}{c}0.139 \\
(9.326)^{*}\end{array}$ & $\begin{array}{c}0.139 \\
(9.366)^{*}\end{array}$ & $\begin{array}{c}0.139 \\
(9.365)^{*}\end{array}$ \\
\hline Age: $45-54$ & - & - & $\begin{array}{c}0.123 \\
(6.355)^{*}\end{array}$ & $\begin{array}{c}0.131 \\
(6.791)^{*}\end{array}$ & $\begin{array}{c}0.133 \\
(6.848)^{*}\end{array}$ & $\begin{array}{c}0.136 \\
(7.053)^{*}\end{array}$ & $\begin{array}{c}0.137 \\
(7.053)^{*}\end{array}$ \\
\hline Age: $55-60$ & - & - & $\begin{array}{c}0.029 \\
(2.382)^{*}\end{array}$ & $\begin{array}{c}0.031 \\
(2.520)^{*}\end{array}$ & $\begin{array}{c}0.029 \\
(2.372)^{*}\end{array}$ & $\begin{array}{c}0.030 \\
(2.483)^{*}\end{array}$ & $\begin{array}{c}0.031 \\
(2.485)^{*}\end{array}$ \\
\hline Region: Mid-West & - & - & $\begin{array}{l}-0.015 \\
(-0.904)\end{array}$ & $\begin{array}{l}-0.017 \\
(-1.028)\end{array}$ & $\begin{array}{l}-0.013 \\
(-0.752)\end{array}$ & $\begin{array}{l}-0.015 \\
(-0.891)\end{array}$ & $\begin{array}{l}-0.015 \\
(-0.881)\end{array}$ \\
\hline Region: North & - & - & $\begin{array}{l}-0.002 \\
(-0.090)\end{array}$ & $\begin{array}{l}-0.007 \\
(-0.396)\end{array}$ & $\left(\begin{array}{l}-0.006 \\
(-0.333)\end{array}\right.$ & $\begin{array}{l}-0.009 \\
(-0.507)\end{array}$ & $\begin{array}{l}-0.008 \\
(-0.498)\end{array}$ \\
\hline Region: South & - & - & $\left(\begin{array}{l}0.003 \\
0.186\end{array}\right)$ & $\left(\begin{array}{l}0.001 \\
0.079\end{array}\right)$ & $\left.\begin{array}{l}0.006 \\
0.409\end{array}\right)$ & $\left(\begin{array}{l}0.004 \\
0.263\end{array}\right)$ & $\left(\begin{array}{l}0.004 \\
0.272\end{array}\right)$ \\
\hline Years of Education & - & - & $\begin{array}{c}0.024 \\
(8.733)^{*}\end{array}$ & $\begin{array}{c}0.022 \\
(8.039)^{*}\end{array}$ & $\begin{array}{c}0.022 \\
(8.098)^{*}\end{array}$ & $\begin{array}{c}0.021 \\
(7.729)^{*}\end{array}$ & $\begin{array}{c}0.021 \\
(7.729)^{*}\end{array}$ \\
\hline Female & - & - & $\left(\begin{array}{c}-0.179 \\
-13.045)^{*}\end{array}\right.$ & $\left(\begin{array}{c}-0.171 \\
-12.527\end{array}\right)^{*}$ & $\begin{array}{c}-0.168 \\
(-12.207)^{*}\end{array}$ & $\left(\begin{array}{c}-0.166 \\
-12.021)^{*}\end{array}\right.$ & $\left(\begin{array}{c}-0.166 \\
-12.005)^{*}\end{array}\right.$ \\
\hline Foreigner & - & - & $(-0.075) *$ & $\begin{array}{c}-0.069 \\
(-5.126)^{*}\end{array}$ & $\begin{array}{c}-0.069 \\
(-5.147)^{*}\end{array}$ & $\begin{array}{l}-0.066 \\
(-4.916)^{*}\end{array}$ & $\begin{array}{c}-0.066 \\
(-4.866) *\end{array}$ \\
\hline Firm Size: Under 20 & - & - & $\left(\begin{array}{c}-0.196 \\
-10.850)^{*}\end{array}\right.$ & $\left(\begin{array}{c}-0.190 \\
-10.562)^{*}\end{array}\right.$ & $\left(\begin{array}{c}-0.192 \\
-10.677)^{*}\end{array}\right.$ & $\begin{array}{c}-0.188 \\
(-10.496)^{*}\end{array}$ & $\left(\begin{array}{c}-0.188 \\
-10.467)^{*}\end{array}\right.$ \\
\hline Firm Size: 20-199 & - & - & $\begin{array}{c}-0.122 \\
(-7.725)^{*}\end{array}$ & $\begin{array}{c}-0.116 \\
(-7.367)^{*}\end{array}$ & $\begin{array}{c}-0.120 \\
(-7.605)^{*}\end{array}$ & $\begin{array}{l}-0.115 \\
(-7.353)^{*}\end{array}$ & $\begin{array}{c}-0.115 \\
(-7.336)^{*}\end{array}$ \\
\hline Firm Size: 200-1999 & - & - & $\begin{array}{c}-0.082 \\
(-5.466)^{*}\end{array}$ & $\left(\begin{array}{l}-0.077 \\
-5.165)^{*}\end{array}\right.$ & $\begin{array}{c}-0.079 \\
(-5.300)^{*}\end{array}$ & $\begin{array}{l}-0.076 \\
(-5.107)^{*}\end{array}$ & $\begin{array}{c}-0.076 \\
(-5.102) *\end{array}$ \\
\hline Occ: Business & - & - & $\left.\begin{array}{l}0.000 \\
0.000\end{array}\right)$ & $\begin{array}{l}-0.008 \\
(-0.214)\end{array}$ & $\left.\begin{array}{l}0.003 \\
(0.080\end{array}\right)$ & $\left(\begin{array}{l}-0.004 \\
-0.112\end{array}\right)$ & $\left(\begin{array}{l}-0.004 \\
-0.120\end{array}\right)$ \\
\hline Occ: Manager & - & - & $\begin{array}{c}0.377 \\
(8.760)^{*}\end{array}$ & $\begin{array}{c}0.358 \\
(8.328)^{*}\end{array}$ & $\begin{array}{c}0.366 \\
(8.531)^{*}\end{array}$ & $\begin{array}{c}0.354 \\
(8.251)^{*}\end{array}$ & $\begin{array}{c}0.354 \\
(8.251)^{*}\end{array}$ \\
\hline Occ: Manufacturing & - & - & $\begin{array}{c}0.100 \\
(3.500)^{*}\end{array}$ & $\begin{array}{c}0.102 \\
(3.576)^{*}\end{array}$ & $\begin{array}{c}0.107 \\
(3.755)^{*}\end{array}$ & $\begin{array}{c}0.106 \\
(3.743)^{*}\end{array}$ & $\begin{array}{c}0.106 \\
(3.736)^{*}\end{array}$ \\
\hline Occ: Office & - & - & $\begin{array}{c}0.100 \\
(3.287)^{*}\end{array}$ & $\begin{array}{c}0.073 \\
(2.389)^{*}\end{array}$ & $\begin{array}{c}0.098 \\
(3.258)^{*}\end{array}$ & $\begin{array}{c}0.078 \\
(2.541)^{*}\end{array}$ & $\begin{array}{c}0.078 \\
(2.527)^{*}\end{array}$ \\
\hline Occ: Science & - & - & $\begin{array}{c}0.166 \\
(5.465)^{*}\end{array}$ & $\begin{array}{c}0.156 \\
(5.146)^{*}\end{array}$ & $\begin{array}{c}0.161 \\
(5.324)^{*}\end{array}$ & $\begin{array}{c}0.155 \\
(5.109)^{*}\end{array}$ & $\begin{array}{c}0.155 \\
(5.109)^{*}\end{array}$ \\
\hline 2. Energy & - & - & $\left.\begin{array}{l}0.013 \\
0.383\end{array}\right)$ & $\begin{array}{l}0.014 \\
(0.437)\end{array}$ & $\left.\begin{array}{l}0.008 \\
0.252\end{array}\right)$ & $\left(\begin{array}{l}0.011 \\
0.331\end{array}\right)$ & $\left.\begin{array}{l}0.011 \\
0.329\end{array}\right)$ \\
\hline 3.1 Chemicals & - & - & $\begin{array}{c}0.061 \\
(2.856)^{*}\end{array}$ & $\begin{array}{c}0.055 \\
(2.611)^{*}\end{array}$ & $\begin{array}{c}0.055 \\
(2.596)^{*}\end{array}$ & $\left(\begin{array}{c}0.052 \\
(2.473)^{*}\end{array}\right.$ & $\begin{array}{c}0.052 \\
(2.477)^{*}\end{array}$ \\
\hline 3.2 Plastics & - & - & $\left(\begin{array}{l}0.026 \\
0.650\end{array}\right)$ & $\left(\begin{array}{l}0.025 \\
0.652\end{array}\right)$ & $\left(\begin{array}{l}0.025 \\
0.640\end{array}\right)$ & $\left(\begin{array}{l}0.025 \\
0.645\end{array}\right)$ & $\left.\begin{array}{l}0.025 \\
0.643\end{array}\right)$ \\
\hline 3.3 Stone & - & - & $\left(\begin{array}{l}0.005 \\
0.101)\end{array}\right.$ & $\begin{array}{l}-0.001 \\
-0.024)\end{array}$ & $\left(\begin{array}{l}0.003 \\
0.060\end{array}\right)$ & $\left.\begin{array}{l}-0.001 \\
(-0.028\end{array}\right)$ & $\begin{array}{l}-0.001 \\
(-0.023)\end{array}$ \\
\hline 3.4 Metal & - & - & $\begin{array}{c}0.070 \\
(7.742)^{*}\end{array}$ & $\begin{array}{c}0.064 \\
(7.080)^{*}\end{array}$ & $\begin{array}{c}0.066 \\
(7.297)^{*}\end{array}$ & $\begin{array}{c}0.062 \\
(6.898)^{*}\end{array}$ & $\begin{array}{c}0.062 \\
(6.899)^{*}\end{array}$ \\
\hline 3.5 Wood & - & - & $\begin{array}{l}0.038 \\
(1.418)\end{array}$ & $\begin{array}{l}0.035 \\
(1.305)\end{array}$ & $\begin{array}{l}0.036 \\
(1.351)\end{array}$ & $\begin{array}{l}0.034 \\
(1.280)\end{array}$ & $\begin{array}{l}0.034 \\
(1.278)\end{array}$ \\
\hline 3.6 Textiles & - & - & $\begin{array}{c}-0.164 \\
(-4.243)^{*}\end{array}$ & $\begin{array}{c}-0.160 \\
(-4.162)^{*}\end{array}$ & $\begin{array}{c}-0.163 \\
(-4.219)^{*}\end{array}$ & $\begin{array}{c}-0.160 \\
(-4.161)^{*}\end{array}$ & $\begin{array}{c}-0.160 \\
(-4.158)^{*}\end{array}$ \\
\hline 3.7 Food & - & - & $\begin{array}{l}-0.051 \\
(-1.552)\end{array}$ & $\left.\begin{array}{l}-0.048 \\
(-1.486\end{array}\right)$ & $\left(\begin{array}{l}-0.050 \\
(-1.549)\end{array}\right.$ & $\left.\begin{array}{l}-0.049 \\
(-1.498\end{array}\right)$ & $\left.\begin{array}{l}-0.048 \\
(-1.495\end{array}\right)$ \\
\hline 4. Construction & - & - & $\begin{array}{c}0.050 \\
(2.766)^{*}\end{array}$ & $\begin{array}{c}0.057 \\
(3.185)^{*}\end{array}$ & $\begin{array}{c}0.052 \\
(2.924)^{*}\end{array}$ & $\begin{array}{c}0.057 \\
(3.211)^{*}\end{array}$ & $\begin{array}{c}0.058 \\
(3.215)^{*}\end{array}$ \\
\hline 5. Wholesale/Retail & - & - & $\begin{array}{c}-0.103 \\
(-5.418)^{*}\end{array}$ & $\begin{array}{c}-0.103 \\
(-5.459)^{*}\end{array}$ & $\begin{array}{c}-0.101 \\
(-5.368)^{*}\end{array}$ & $\begin{array}{c}-0.102 \\
(-5.413)^{*}\end{array}$ & $\begin{array}{c}-0.102 \\
(-5.408)^{*}\end{array}$ \\
\hline 6. Transport & - & - & $\begin{array}{c}-0.071 \\
(-2.988)^{*}\end{array}$ & $\begin{array}{c}-0.065 \\
(-2.730)^{*}\end{array}$ & $\begin{array}{c}-0.068 \\
(-2.849)^{*}\end{array}$ & $\begin{array}{c}-0.063 \\
(-2.682)^{*}\end{array}$ & $\begin{array}{c}-0.063 \\
(-2.677)^{*}\end{array}$ \\
\hline 7. Banking & - & - & $\begin{array}{c}0.047 \\
(1.841)^{*}\end{array}$ & $\begin{array}{c}0.045 \\
(1.803)^{*}\end{array}$ & $\begin{array}{c}0.049 \\
(1.952)^{*}\end{array}$ & $\begin{array}{c}0.048 \\
(1.891)^{*}\end{array}$ & $\begin{array}{c}0.047 \\
(1.887)^{*}\end{array}$ \\
\hline 8. Other Services & - & - & $\begin{array}{c}-0.092 \\
(-5.910)^{*}\end{array}$ & $\begin{array}{c}-0.087 \\
(-5.572)^{*}\end{array}$ & $\begin{array}{c}-0.087 \\
(-5.612)^{*}\end{array}$ & $\begin{array}{c}-0.084 \\
(-5.427)^{*}\end{array}$ & $\begin{array}{c}-0.084 \\
(-5.428)^{*}\end{array}$ \\
\hline 9. Non-Profit & - & - & $\left.\begin{array}{c}-0.044 \\
(-1.329\end{array}\right)$ & $\left(\begin{array}{l}-0.033 \\
(-1.002)\end{array}\right.$ & $\begin{array}{l}-0.034 \\
(-1.028)\end{array}$ & $\begin{array}{l}-0.028 \\
(-0.853)\end{array}$ & $\begin{array}{l}-0.029 \\
(-0.857)\end{array}$ \\
\hline White Collar & - & - & $\begin{array}{c}0.149 \\
(7.322)^{*}\end{array}$ & $\begin{array}{c}0.126 \\
(6.063)^{*}\end{array}$ & $\begin{array}{c}0.137 \\
(6.710)^{*}\end{array}$ & $\begin{array}{c}0.122 \\
(5.885)^{*}\end{array}$ & $\begin{array}{c}0.122 \\
(5.884)^{*}\end{array}$ \\
\hline
\end{tabular}


Table 8: Standard Longitudinal Model with: PC-Work

\begin{tabular}{|c|c|c|c|}
\hline $\begin{array}{l}\text { Model } \\
\text { Observations }\end{array}$ & POOLED OLS & RE-PANEL & $\begin{array}{l}\text { FE-PANEL } \\
12482\end{array}$ \\
\hline Individuals & - & 1625 & 1625 \\
\hline $\mathrm{R}^{2}$ & 0.459 & 0.391 & 0.140 \\
\hline $\begin{array}{l}\text { F-Test / }\left(\mathrm{Chi}^{2} \text { for REP }\right) \\
\text { Prob }\end{array}$ & $\begin{array}{c}239.650 \\
0.000\end{array}$ & $\begin{array}{c}5282.980 \\
0.000\end{array}$ & $\begin{array}{c}103.530 \\
0.000\end{array}$ \\
\hline PC-Work & $\begin{array}{c}0.086 \\
(14.859)^{*}\end{array}$ & $\begin{array}{c}0.042 \\
(7.108)^{*}\end{array}$ & $\begin{array}{c}0.021 \\
(3.254)^{*}\end{array}$ \\
\hline Constant & $\begin{array}{c}3.712 \\
(152.227)^{*}\end{array}$ & $\begin{array}{c}3.613 \\
(111.807)^{*}\end{array}$ & $\left.\begin{array}{c}3.770 \\
(55.747\end{array}\right)^{*}$ \\
\hline Age: $25-34$ & $\begin{array}{c}0.087 \\
(17.193)^{*}\end{array}$ & $\begin{array}{c}0.070 \\
(13.885)^{*}\end{array}$ & $\begin{array}{c}0.028 \\
(4.637)^{*}\end{array}$ \\
\hline Age: $35-44$ & $\begin{array}{c}0.118 \\
(21.098)^{*}\end{array}$ & $\begin{array}{c}0.066 \\
(8.629)^{*}\end{array}$ & $\begin{array}{c}-0.019 \\
(-1.866)^{*}\end{array}$ \\
\hline Age: $45-54$ & $\begin{array}{c}0.119 \\
(10.877)^{*}\end{array}$ & $\begin{array}{c}0.041 \\
(3.460)^{*}\end{array}$ & $\begin{array}{c}-0.080 \\
(-5.395)^{*}\end{array}$ \\
\hline Age: $55-60$ & $\begin{array}{c}0.075 \\
(15.405)^{*}\end{array}$ & $\begin{array}{c}0.056 \\
(10.104)^{*}\end{array}$ & $\begin{array}{c}0.037 \\
(6.027)^{*}\end{array}$ \\
\hline Region: Mid-West & $\begin{array}{c}-0.012 \\
(-1.775)^{*}\end{array}$ & $\begin{array}{l}-0.015 \\
(-1.028)\end{array}$ & $\begin{array}{c}0.100 \\
(2.634)^{*}\end{array}$ \\
\hline Region: North & $\begin{array}{c}-0.014 \\
(-2.060)^{*}\end{array}$ & $\begin{array}{l}-0.014 \\
(-0.999)\end{array}$ & $\left.\begin{array}{l}-0.037 \\
(-0.947\end{array}\right)$ \\
\hline Region: South & $\begin{array}{l}0.005 \\
(0.917)\end{array}$ & $\begin{array}{c}0.028 \\
(2.481)^{*}\end{array}$ & $\begin{array}{c}0.209 \\
(6.370)^{*}\end{array}$ \\
\hline Years of Education & $\begin{array}{c}0.029 \\
(26.176)^{*}\end{array}$ & $\begin{array}{c}0.039 \\
(18.665)^{*}\end{array}$ & $\begin{array}{c}0.026 \\
(4.605)^{*}\end{array}$ \\
\hline Firm Size: Under 20 & $\left(\begin{array}{c}-0.186 \\
-26.045)^{*}\end{array}\right.$ & $\left(\begin{array}{c}-0.119 \\
(-14.969\end{array}\right)^{*}$ & $\begin{array}{c}-0.082 \\
(-9.516)^{*}\end{array}$ \\
\hline Firm Size: 20-199 & $\left(\begin{array}{c}-0.126 \\
-21.645\end{array}\right)^{*}$ & $\left(\begin{array}{c}-0.071 \\
-11.202)^{*}\end{array}\right.$ & $\begin{array}{c}-0.045 \\
(-6.581)^{*}\end{array}$ \\
\hline Firm Size: 200-1999 & $\left(\begin{array}{c}-0.072 \\
(-13.036\end{array}\right)^{*}$ & $\begin{array}{c}-0.026 \\
(-4.769)^{*}\end{array}$ & $\begin{array}{c}-0.009 \\
(-1.675)^{*}\end{array}$ \\
\hline Occ: Business & $\begin{array}{c}0.036 \\
(2.085)^{*}\end{array}$ & $\begin{array}{c}0.039 \\
(2.233)^{*}\end{array}$ & $\left(\begin{array}{l}0.027 \\
1.423\end{array}\right)$ \\
\hline Occ: Manager & $\begin{array}{c}0.318 \\
(16.054)^{*}\end{array}$ & $\begin{array}{c}0.121 \\
(6.627)^{*}\end{array}$ & $\begin{array}{c}0.051 \\
(2.629)^{*}\end{array}$ \\
\hline Occ: Manufacturing & $\begin{array}{c}0.120 \\
(9.617)^{*}\end{array}$ & $\begin{array}{c}0.064 \\
(4.601)^{*}\end{array}$ & $\begin{array}{c}0.033 \\
(2.168)^{*}\end{array}$ \\
\hline Occ: Office & $\begin{array}{c}0.049 \\
(3.572)^{*}\end{array}$ & $\begin{array}{c}0.049 \\
(3.257)^{*}\end{array}$ & $\left(\begin{array}{l}0.022 \\
1.308\end{array}\right)$ \\
\hline Occ: Science & $\begin{array}{c}0.181 \\
(13.272)^{*}\end{array}$ & $\begin{array}{c}0.094 \\
(6.459)^{*}\end{array}$ & $\begin{array}{c}0.038 \\
(2.405)^{*}\end{array}$ \\
\hline 2. Energy & $\begin{array}{c}0.088 \\
(7.257)^{*}\end{array}$ & $\begin{array}{c}0.061 \\
(3.931)^{*}\end{array}$ & $\begin{array}{c}0.041 \\
(2.358)^{*}\end{array}$ \\
\hline 3.1 Chemicals & $\begin{array}{c}0.057 \\
(7.061)^{*}\end{array}$ & $\begin{array}{c}0.031 \\
(2.904)^{*}\end{array}$ & $\left.\begin{array}{l}0.012 \\
0.986\end{array}\right)$ \\
\hline 3.2 Plastics & $\begin{array}{c}-0.070 \\
(-5.240)^{*}\end{array}$ & $\begin{array}{l}0.009 \\
(0.648)\end{array}$ & $\begin{array}{l}0.022 \\
(1.478)\end{array}$ \\
\hline 3.3 Stone & $\left.\begin{array}{l}0.002 \\
(0.149\end{array}\right)$ & $\begin{array}{l}0.013 \\
0.790)\end{array}$ & $\left(\begin{array}{l}0.018 \\
1.008)\end{array}\right.$ \\
\hline 3.4 Metal & $\begin{array}{c}0.055 \\
(17.905)^{*}\end{array}$ & $\begin{array}{c}0.038 \\
(9.309)^{*}\end{array}$ & $\begin{array}{c}0.029 \\
(6.167)^{*}\end{array}$ \\
\hline 3.5 Wood & $\begin{array}{l}0.016 \\
(1.620)\end{array}$ & $\begin{array}{c}-0.027 \\
(-2.239)^{*}\end{array}$ & $\begin{array}{c}-0.024 \\
(-1.869)^{*}\end{array}$ \\
\hline 3.6 Textiles & $\begin{array}{c}-0.131 \\
(-10.557)^{*}\end{array}$ & $\begin{array}{c}-0.039 \\
(-2.738)^{*}\end{array}$ & $\left(\begin{array}{l}0.003 \\
0.186\end{array}\right)$ \\
\hline 3.7 Food & $\begin{array}{c}-0.101 \\
(-8.271)^{*}\end{array}$ & $\begin{array}{c}-0.046 \\
(-3.176)^{*}\end{array}$ & $\begin{array}{l}-0.013 \\
(-0.851)\end{array}$ \\
\hline 4. Construction & $\begin{array}{c}0.078 \\
(11.283)^{*}\end{array}$ & $\left(\begin{array}{l}0.014 \\
(1.603)\end{array}\right.$ & $\left(\begin{array}{l}0.002 \\
0.233)\end{array}\right.$ \\
\hline 5. Wholesale/Retail & $\left(\begin{array}{c}-0.112 \\
(-13.414\end{array}\right)^{*}$ & $\begin{array}{c}-0.037 \\
(-4.664)^{*}\end{array}$ & $\left(\begin{array}{l}-0.005 \\
(-0.611)\end{array}\right.$ \\
\hline 6. Transport & $\begin{array}{c}-0.050 \\
(-5.258)^{*}\end{array}$ & $\begin{array}{c}-0.043 \\
(-3.544)^{*}\end{array}$ & $\begin{array}{c}-0.030 \\
(-2.213)^{*}\end{array}$ \\
\hline 7. Banking & $\begin{array}{c}0.029 \\
(3.018)^{*}\end{array}$ & $\begin{array}{l}0.017 \\
(1.039)\end{array}$ & $\begin{array}{c}-0.042 \\
(-1.710)^{*}\end{array}$ \\
\hline 8. Other Services & $\left(\begin{array}{c}-0.112 \\
(-16.946)\end{array}\right)^{*}$ & $\begin{array}{c}-0.075 \\
(-9.314)^{*}\end{array}$ & $\begin{array}{c}-0.052 \\
(-5.637)^{*}\end{array}$ \\
\hline 9. Non-Profit & $\begin{array}{c}-0.102 \\
(-6.847)^{*}\end{array}$ & $\begin{array}{c}-0.095 \\
(-5.801)^{*}\end{array}$ & $\begin{array}{c}-0.068 \\
(-3.742)^{*}\end{array}$ \\
\hline White Collar & $\begin{array}{c}0.146 \\
(18.339)^{*}\end{array}$ & $\begin{array}{c}0.041 \\
(5.666)^{*}\end{array}$ & $\begin{array}{l}0.012 \\
(1.608)\end{array}$ \\
\hline
\end{tabular}


Table 9: Standard Longitudinal Model with: PC-Work \& PC-Home

\begin{tabular}{|c|c|c|c|}
\hline $\begin{array}{l}\text { Model } \\
\text { Observations } \\
\text { Individuals } \\
\mathrm{R}^{2} \\
\text { F-Test } \\
\text { Prob / }\left(\mathrm{Chi}^{2} \text { for REP }\right)\end{array}$ & $\begin{array}{c}\text { POOLED OLS } \\
12482 \\
- \\
0.467 \\
241.660 \\
0.000\end{array}$ & $\begin{array}{c}\text { RE-PANEL } \\
12482 \\
1625 \\
0.399 \\
5325.200 \\
0.000\end{array}$ & $\begin{array}{l}\text { FE-PANEL } \\
12482 \\
1625 \\
0.142 \\
101.360 \\
0.000\end{array}$ \\
\hline PC-Work & $\begin{array}{c}0.060 \\
(9.857)^{*}\end{array}$ & $\begin{array}{c}0.033 \\
(5.362)^{*}\end{array}$ & $\begin{array}{c}0.017 \\
(2.575)^{*}\end{array}$ \\
\hline PC-Home & $\begin{array}{c}0.090 \\
(13.383)^{*}\end{array}$ & $\begin{array}{c}0.034 \\
(5.090)^{*}\end{array}$ & $\begin{array}{c}0.015 \\
(2.062)^{*}\end{array}$ \\
\hline Constant & $\begin{array}{c}3.725 \\
(153.734)^{*}\end{array}$ & $\begin{array}{c}3.621 \\
(112.326)^{*}\end{array}$ & $\begin{array}{c}3.774 \\
(55.789)^{*}\end{array}$ \\
\hline Age: $25-34$ & $\begin{array}{c}0.088 \\
(17.579)^{*}\end{array}$ & $\begin{array}{c}0.071 \\
(14.013) *\end{array}$ & $\begin{array}{c}0.028 \\
(4.633)^{*}\end{array}$ \\
\hline Age: $35-44$ & $\begin{array}{c}0.122 \\
(21.898)^{*}\end{array}$ & $\begin{array}{c}0.068 \\
(8.844) *\end{array}$ & $\begin{array}{c}-0.018 \\
(-1.854) *\end{array}$ \\
\hline Age: $45-54$ & $\begin{array}{c}0.128 \\
(11.791)^{*}\end{array}$ & $\begin{array}{c}0.045 \\
(3.763)^{*}\end{array}$ & $\begin{array}{c}-0.079 \\
(-5.338) *\end{array}$ \\
\hline Age: $55-60$ & $\left(\begin{array}{c}0.073 \\
(15.146)^{*}\end{array}\right.$ & $\begin{array}{c}0.055 \\
(9.968)^{*}\end{array}$ & $\begin{array}{c}0.036 \\
(5.938)^{*}\end{array}$ \\
\hline Region: Mid-West & $\begin{array}{l}-0.008 \\
(-1.158)\end{array}$ & $\begin{array}{l}-0.012 \\
(-0.867)\end{array}$ & $\begin{array}{c}0.103 \\
(2.719)^{*}\end{array}$ \\
\hline Region: North & $\begin{array}{c}-0.015 \\
(-2.320)^{*}\end{array}$ & $\left(\begin{array}{l}-0.015 \\
-1.053)\end{array}\right.$ & $\begin{array}{l}-0.036 \\
(-0.934)\end{array}$ \\
\hline Region: South & $\left(\begin{array}{l}0.008 \\
1.515\end{array}\right)$ & $\begin{array}{c}0.029 \\
(2.613)^{*}\end{array}$ & $\begin{array}{c}0.209 \\
(6.396)^{*}\end{array}$ \\
\hline Years of Education & $\begin{array}{c}0.028 \\
(25.256)^{*}\end{array}$ & $\begin{array}{c}0.038 \\
(18.258)^{*}\end{array}$ & $\begin{array}{c}0.025 \\
(4.516)^{*}\end{array}$ \\
\hline Firm Size: Under 20 & $\begin{array}{c}-0.184 \\
(-25.934) *\end{array}$ & $\left.\begin{array}{c}-0.119 \\
(-14.885\end{array}\right)^{*}$ & $\begin{array}{c}-0.082 \\
(-9.466)^{*}\end{array}$ \\
\hline Firm Size: 20-199 & $\left(\begin{array}{c}-0.123 \\
-21.234\end{array}\right)^{*}$ & $\left(\begin{array}{c}-0.070 \\
(-11.042)^{*}\end{array}\right.$ & $\begin{array}{c}-0.044 \\
(-6.502)^{*}\end{array}$ \\
\hline Firm Size: 200-1999 & $\begin{array}{c}-0.069 \\
(-12.624)^{*}\end{array}$ & $\begin{array}{c}-0.025 \\
(-4.647)^{*}\end{array}$ & $\begin{array}{l}-0.009 \\
(-1.618)\end{array}$ \\
\hline Occ: Business & $\begin{array}{c}0.043 \\
(2.507)^{*}\end{array}$ & $\begin{array}{c}0.042 \\
(2.390)^{*}\end{array}$ & $\begin{array}{l}0.028 \\
(1.485)\end{array}$ \\
\hline Occ: Manager & $\begin{array}{c}0.302 \\
(15.354)^{*}\end{array}$ & $\begin{array}{c}0.120 \\
(6.542)^{*}\end{array}$ & $\begin{array}{c}0.050 \\
(2.596)^{*}\end{array}$ \\
\hline Occ: Manufacturing & $\begin{array}{c}0.125 \\
(10.086)^{*}\end{array}$ & $\begin{array}{c}0.064 \\
(4.655)^{*}\end{array}$ & $\begin{array}{c}0.033 \\
(2.173)^{*}\end{array}$ \\
\hline Occ: Office & $\begin{array}{c}0.057 \\
(4.160)^{*}\end{array}$ & $\begin{array}{c}0.050 \\
(3.363)^{*}\end{array}$ & $\begin{array}{l}0.022 \\
(1.338)\end{array}$ \\
\hline Occ: Science & $\begin{array}{c}0.176 \\
(13.029)^{*}\end{array}$ & $\begin{array}{c}0.094 \\
(6.466)^{*}\end{array}$ & $\begin{array}{c}0.039 \\
(2.415)^{*}\end{array}$ \\
\hline 2. Energy & $\begin{array}{c}0.081 \\
(6.791)^{*}\end{array}$ & $\begin{array}{c}0.061 \\
(3.964)^{*}\end{array}$ & $\begin{array}{c}0.041 \\
(2.390)^{*}\end{array}$ \\
\hline 3.1 Chemicals & $\begin{array}{c}0.056 \\
(7.073)^{*}\end{array}$ & $\begin{array}{c}0.032 \\
(2.984)^{*}\end{array}$ & $\begin{array}{l}0.012 \\
(1.033)\end{array}$ \\
\hline 3.2 Plastics & $\begin{array}{c}-0.072 \\
(-5.388)^{*}\end{array}$ & $\left(\begin{array}{l}0.009 \\
0.660)\end{array}\right)$ & $\begin{array}{l}0.022 \\
(1.498)\end{array}$ \\
\hline 3.3 Stone & $\begin{array}{l}0.003 \\
0.163)\end{array}$ & $\left(\begin{array}{l}0.016 \\
0.946\end{array}\right)$ & $\begin{array}{l}0.019 \\
(1.086)\end{array}$ \\
\hline 3.4 Metal & $\begin{array}{c}0.052 \\
(17.059)^{*}\end{array}$ & $\begin{array}{c}0.037 \\
(9.299)^{*}\end{array}$ & $\begin{array}{c}0.029 \\
(6.179)^{*}\end{array}$ \\
\hline 3.5 Wood & $\begin{array}{c}0.015 \\
(1.568)^{*}\end{array}$ & $\begin{array}{c}-0.028 \\
(-2.375)^{*}\end{array}$ & $\begin{array}{c}-0.025 \\
(-1.944)^{*}\end{array}$ \\
\hline 3.6 Textiles & $\left(\begin{array}{c}-0.131 \\
-10.639\end{array}\right)^{*}$ & $\begin{array}{c}-0.041 \\
(-2.824)^{*}\end{array}$ & $\begin{array}{l}0.002 \\
(0.151)\end{array}$ \\
\hline 3.7 Food & $\begin{array}{c}-0.099 \\
(-8.232)^{*}\end{array}$ & $\begin{array}{c}-0.047 \\
(-3.210)^{*}\end{array}$ & $\left(\begin{array}{l}-0.014 \\
(-0.871)\end{array}\right.$ \\
\hline 4. Construction & $\begin{array}{c}0.077 \\
(11.230)^{*}\end{array}$ & $\begin{array}{l}0.014 \\
(1.618)\end{array}$ & $\begin{array}{l}0.002 \\
(0.222)\end{array}$ \\
\hline 5. Wholesale/Retail & $\left(\begin{array}{c}-0.110 \\
(-13.228)^{*}\end{array}\right.$ & $\begin{array}{c}-0.039 \\
(-4.836)^{*}\end{array}$ & $\left(\begin{array}{l}-0.006 \\
(-0.682)\end{array}\right.$ \\
\hline 6. Transport & $\begin{array}{c}-0.049 \\
(-5.249)^{*}\end{array}$ & $\begin{array}{c}-0.042 \\
(-3.520)^{*}\end{array}$ & $\begin{array}{c}-0.030 \\
(-2.201)^{*}\end{array}$ \\
\hline 7. Banking & $\begin{array}{c}0.037 \\
(3.892)^{*}\end{array}$ & $\left(\begin{array}{l}0.020 \\
1.201)\end{array}\right.$ & $\begin{array}{c}-0.041 \\
(-1.671)^{*}\end{array}$ \\
\hline 8. Other Services & $\begin{array}{c}-0.108 \\
(-16.419)^{*}\end{array}$ & $\begin{array}{c}-0.075 \\
(-9.341)^{*}\end{array}$ & $\begin{array}{c}-0.053 \\
(-5.656)^{*}\end{array}$ \\
\hline 9. Non-Profit & $\begin{array}{c}-0.094 \\
(-6.390)^{*}\end{array}$ & $\begin{array}{c}-0.096 \\
(-5.833)^{*}\end{array}$ & $\begin{array}{c}-0.068 \\
(-3.774)^{*}\end{array}$ \\
\hline White Collar & $\begin{array}{c}0.142 \\
(17.998)^{*}\end{array}$ & $\begin{array}{c}0.041 \\
(5.671)^{*}\end{array}$ & $\begin{array}{l}0.013 \\
(1.627)\end{array}$ \\
\hline
\end{tabular}


Table 10: Standard Longitudinal Model with: PC-Work, PC-Home \& PC-Both

\begin{tabular}{|c|c|c|c|}
\hline $\begin{array}{l}\text { Model } \\
\text { Observations }\end{array}$ & $\begin{array}{l}\text { POOLED OLS } \\
12482\end{array}$ & $\begin{array}{l}\text { RE-PANEL } \\
12482\end{array}$ & $\begin{array}{l}\text { FE-PANEL } \\
12482\end{array}$ \\
\hline Individuals & - & 1625 & 1625 \\
\hline $\mathrm{R}^{2}$ & 0.467 & 0.399 & 0.142 \\
\hline $\begin{array}{l}\text { F-Test } /\left(\mathrm{Chi}^{2} \text { for REP }\right) \\
\text { Prob }\end{array}$ & $\begin{array}{l}236.470 \\
0.000\end{array}$ & $\begin{array}{l}5325.530 \\
0.000\end{array}$ & $\begin{array}{l}99.170 \\
0.000\end{array}$ \\
\hline PC-Work & $\begin{array}{c}0.063 \\
(9.714)^{*}\end{array}$ & $\begin{array}{c}0.031 \\
(4.727)^{*}\end{array}$ & $\begin{array}{c}0.014 \\
(2.056)^{*}\end{array}$ \\
\hline PC-Home & $\begin{array}{c}0.105 \\
(8.150)^{*}\end{array}$ & $\begin{array}{c}0.027 \\
(2.311)^{*}\end{array}$ & $\begin{array}{l}0.005 \\
(0.436)\end{array}$ \\
\hline PC-Both & $\begin{array}{l}-0.020 \\
(-1.365)\end{array}$ & $\left(\begin{array}{l}0.010 \\
0.779)\end{array}\right.$ & $\begin{array}{l}0.013 \\
(0.977)\end{array}$ \\
\hline Constant & $\begin{array}{c}3.724 \\
(153.560)^{*}\end{array}$ & $\begin{array}{c}3.621 \\
(112.308)^{*}\end{array}$ & $\left(\begin{array}{c}3.774 \\
(55.792)^{*}\end{array}\right.$ \\
\hline Age: $25-34$ & $\begin{array}{c}0.088 \\
(17.600)^{*}\end{array}$ & $\begin{array}{c}0.071 \\
(14.000)^{*}\end{array}$ & $\begin{array}{c}0.028 \\
(4.629)^{*}\end{array}$ \\
\hline Age: $35-44$ & $\left(\begin{array}{c}0.122 \\
21.938)^{*}\end{array}\right.$ & $\begin{array}{c}0.068 \\
(8.821)^{*}\end{array}$ & $\begin{array}{c}-0.019 \\
(-1.863)^{*}\end{array}$ \\
\hline Age: $45-54$ & $\begin{array}{c}0.128 \\
(11.832)^{*}\end{array}$ & $\begin{array}{c}0.045 \\
(3.742)^{*}\end{array}$ & $\begin{array}{l}-0.079 \\
(-5.349) *\end{array}$ \\
\hline Age: $55-60$ & $\begin{array}{c}0.074 \\
(15.162)^{*}\end{array}$ & $\begin{array}{c}0.055 \\
(9.971)^{*}\end{array}$ & $\begin{array}{c}0.036 \\
(5.952)^{*}\end{array}$ \\
\hline Region: Mid-West & $\begin{array}{l}-0.007 \\
(-1.094)\end{array}$ & $\begin{array}{l}-0.012 \\
(-0.864)\end{array}$ & $\begin{array}{c}0.104 \\
(2.751)^{*}\end{array}$ \\
\hline Region: North & $\begin{array}{l}-0.015 \\
(-2.265)^{*}\end{array}$ & $\left(\begin{array}{l}-0.015 \\
(-1.061)\end{array}\right.$ & $\begin{array}{l}-0.036 \\
(-0.929)\end{array}$ \\
\hline Region: South & $\begin{array}{l}0.008 \\
(1.579)\end{array}$ & $\begin{array}{c}0.029 \\
(2.600)^{*}\end{array}$ & $\begin{array}{c}0.209 \\
(6.396)^{*}\end{array}$ \\
\hline Years of Education & $\begin{array}{c}0.028 \\
(25.274)^{*}\end{array}$ & $\begin{array}{c}0.038 \\
(18.248)^{*}\end{array}$ & $\begin{array}{c}0.025 \\
(4.515)^{*}\end{array}$ \\
\hline Firm Size: Under 20 & $\left(\begin{array}{c}-0.184 \\
-25.886)^{*}\end{array}\right.$ & $\begin{array}{c}-0.119 \\
-14.897)^{*}\end{array}$ & $\begin{array}{c}-0.082 \\
(-9.483) *\end{array}$ \\
\hline Firm Size: 20-199 & $\left(\begin{array}{c}-0.123 \\
-21.158\end{array}\right)^{*}$ & $\left(\begin{array}{c}-0.070 \\
-11.052)^{*}\end{array}\right.$ & $\left(\begin{array}{l}-0.044 \\
-6.511)^{*}\end{array}\right.$ \\
\hline Firm Size: 200-1999 & $\left(\begin{array}{c}-0.069 \\
-12.612)^{*}\end{array}\right.$ & $\begin{array}{l}-0.025 \\
(-4.652)^{*}\end{array}$ & $\begin{array}{l}-0.009 \\
(-1.623)\end{array}$ \\
\hline Occ: Business & $\begin{array}{c}0.043 \\
(2.517)^{*}\end{array}$ & $\begin{array}{c}0.042 \\
(2.399)^{*}\end{array}$ & $\left.\begin{array}{l}0.028 \\
(1.496\end{array}\right)$ \\
\hline Occ: Manager & $\begin{array}{c}0.303 \\
(15.394)^{*}\end{array}$ & $\begin{array}{c}0.119 \\
(6.527)^{*}\end{array}$ & $\begin{array}{c}0.050 \\
(2.581)^{*}\end{array}$ \\
\hline Occ: Manufacturing & $\begin{array}{c}0.125 \\
(10.080)^{*}\end{array}$ & $\begin{array}{c}0.064 \\
(4.655)^{*}\end{array}$ & $\begin{array}{c}0.033 \\
(2.172)^{*}\end{array}$ \\
\hline Occ: Office & $\begin{array}{c}0.056 \\
(4.123)^{*}\end{array}$ & $\begin{array}{c}0.051 \\
(3.382)^{*}\end{array}$ & $\begin{array}{l}0.023 \\
(1.357)\end{array}$ \\
\hline Occ: Science & $\begin{array}{c}0.177 \\
(13.062)^{*}\end{array}$ & $\begin{array}{c}0.094 \\
(6.461)^{*}\end{array}$ & $\begin{array}{c}0.039 \\
(2.414)^{*}\end{array}$ \\
\hline 2. Energy & $\begin{array}{c}0.082 \\
(6.824)^{*}\end{array}$ & $\begin{array}{c}0.061 \\
(3.917)^{*}\end{array}$ & $\begin{array}{c}0.040 \\
(2.325)^{*}\end{array}$ \\
\hline 3.1 Chemicals & $\begin{array}{c}0.056 \\
(7.076)^{*}\end{array}$ & $\begin{array}{c}0.032 \\
(2.990)^{*}\end{array}$ & $\begin{array}{l}0.013 \\
(1.045)\end{array}$ \\
\hline 3.2 Plastics & $\begin{array}{c}-0.072 \\
(-5.392)^{*}\end{array}$ & $\begin{array}{l}0.009 \\
(0.671)\end{array}$ & $\begin{array}{l}0.023 \\
(1.516)\end{array}$ \\
\hline 3.3 Stone & $\begin{array}{c}0.002 \\
(0.143)^{*}\end{array}$ & $\begin{array}{l}0.016 \\
(0.939)\end{array}$ & $\begin{array}{l}0.019 \\
(1.075)\end{array}$ \\
\hline 3.4 Metal & $\begin{array}{c}0.052 \\
(17.053)^{*}\end{array}$ & $\begin{array}{c}0.037 \\
(9.307)^{*}\end{array}$ & $\begin{array}{c}0.029 \\
(6.190)^{*}\end{array}$ \\
\hline 3.5 Wood & $\begin{array}{c}0.016 \\
(1.593)^{*}\end{array}$ & $\begin{array}{c}-0.028 \\
(-2.378)^{*}\end{array}$ & $\begin{array}{c}-0.025 \\
(-1.943)^{*}\end{array}$ \\
\hline 3.6 Textiles & $\left(\begin{array}{c}-0.131 \\
-10.617)^{*}\end{array}\right.$ & $\begin{array}{c}-0.041 \\
(-2.827)^{*}\end{array}$ & $\begin{array}{c}0.002 \\
(0.152)^{*}\end{array}$ \\
\hline 3.7 Food & $\begin{array}{c}-0.099 \\
(-8.188)^{*}\end{array}$ & $\begin{array}{l}-0.047 \\
(-3.215)^{*}\end{array}$ & $\begin{array}{l}-0.014 \\
(-0.873)\end{array}$ \\
\hline 4. Construction & $\begin{array}{c}0.077 \\
(11.244)^{*}\end{array}$ & $\begin{array}{l}0.014 \\
(1.629)\end{array}$ & $\begin{array}{l}0.002 \\
(0.247)\end{array}$ \\
\hline 5. Wholesale/Retail & $\begin{array}{c}-0.110 \\
(-13.206)^{*}\end{array}$ & $\begin{array}{c}-0.039 \\
(-4.863)^{*}\end{array}$ & $\begin{array}{l}-0.006 \\
(-0.723)\end{array}$ \\
\hline 6. Transport & $\begin{array}{c}-0.049 \\
(-5.239)^{*}\end{array}$ & $\begin{array}{c}-0.042 \\
(-3.518)^{*}\end{array}$ & $\begin{array}{c}-0.030 \\
(-2.198)^{*}\end{array}$ \\
\hline 7. Banking & $\begin{array}{c}0.037 \\
(3.870)^{*}\end{array}$ & $\begin{array}{l}0.020 \\
(1.202)\end{array}$ & $\begin{array}{c}-0.042 \\
(-1.683)^{*}\end{array}$ \\
\hline 8. Other Services & $\begin{array}{c}-0.108 \\
(-16.461)^{*}\end{array}$ & $\begin{array}{c}-0.075 \\
(-9.324)^{*}\end{array}$ & $\begin{array}{c}-0.052 \\
(-5.640)^{*}\end{array}$ \\
\hline 9. Non-Profit & $\begin{array}{c}-0.094 \\
(-6.405)^{*}\end{array}$ & $\begin{array}{c}-0.096 \\
(-5.826)^{*}\end{array}$ & $\begin{array}{c}-0.068 \\
(-3.764)^{*}\end{array}$ \\
\hline White Collar & $\left(\begin{array}{c}0.142 \\
(17.951)^{*}\end{array}\right.$ & $\begin{array}{c}0.042 \\
(5.692)^{*}\end{array}$ & $\begin{array}{c}0.013 \\
(1.651)^{*}\end{array}$ \\
\hline
\end{tabular}

